\title{
Ethanol consumption of rats in individual, group, and colonial housing conditions
}

\author{
PAUL J. KULKOSKY \\ Laboratory of Metabolism, National Institute on Alcohol Abuse and Alcoholism \\ Rockville, Maryland 20852 \\ and \\ DEBRA A. ZELLNER, RICHARD L. HYSON, and ANTHONY L. RILEY \\ The American University, Washington, D.C. 20016
}

\begin{abstract}
Rats were housed in individual cages, in a group cage, or in a naturalistic colonial habitat, and given access to food, water, $10 \%$ ethanol, and $10 \%$ ethanol in a sweetened saline solution. Rats housed in the colony ingested significantly less total ethanol than either group or individually caged rats. When the flavored ethanol solution was removed, total ethanol intakes of all groups decreased and did not differ significantly. The data indicate that the stimuli of the colonial situation act to decrease ethanol intake when a palatable ethanol solution is available.
\end{abstract}

The consumption of and preference for ethanol by infrahuman species have been extensively studied and reviewed (Eriksson, 1969; Lester, 1966; Lester \& Freed, 1973; Mardones, 1960; Mello, 1973, 1976; Myers, 1966; Myers \& Veale, 1972; Richter, 1957; Wallgren \& Barry, 1970; Wise, 1975). These reports have typically been undertaken to provide information ultimately useful for understanding and acting on alcohol use, abuse, and alcoholism in humans.

Any comparative model construed as a "miniature representation" of human behavior and physiology should provide a reasonable analogy to the ordinary conditions of human performance (Lester \& Freed, 1973). However, most studies of infrahuman ethanol consumption examine the intake of ethanol by isolated subjects living in small, standard housing cages. In many experiments, in addition to being isolated, the animals are deprived of food and/or water.

A number of current theories of the determinants of human ethanol consumption stress possible social and cultural factors (Barry, 1968; Noble, 1978; Wallgren \& Barry, 1970). Therefore, factors thought to have an important governing role in human alcohol use are necessarily excluded from consideration when individual caging of animals is employed. Although a number of studies have examined ethanol consumption of animals in cages of varying degrees of grouping (Brown, 1968; Deatherage, 1972; Hannon \& Donlon-Bantz, 1975, 1976; Heminway \& Furumoto, 1972; Parker \& Radow,

Requests for reprints should be sent to Paul J. Kulkosky, now at The Edward W. Bourne Behavioral Research Laboratory, The New York Hospital-Cornell Medical Center, Westchester Division, 21 Bloomingdale Road, White Plains, New York 10605 , or to Anthony L. Riley, Department of Psychology, The American University, Washington, D.C. 20016.
1974; Rodgers \& Thiessen, 1964; Slighter, 1970; Thiessen \& Rodgers, 1965; Wilson, 1969), apparently there have been few studies of animal ethanol consumption in naturalistic habitats which mimic normal ecological and social variables of the species investigated. An analysis that allows for natural environmental and social interactions might better approximate the conditions of human ethanol consumption. In addition, a more naturalistic setting for the analysis of consummatory behavior of infrahuman subjects would eliminate factors such as isolation and deprivation, both of which have been closely associated with stress as indexed by pituitaryadrenal activation and gastric ulceration (Hatch, Wiberg, Balazs, \& Grice, 1963; Lovely, Pagano, \& Paolino, 1972; Paré \& Temple, 1973). Such variables may elevate or depress spontaneous consumption of water and/or ethanol.

In the following experiment, consumption of water, ethanol, and flavored ethanol by rats housed in a naturalistic colony was studied and compared to that of individually and group-housed rats. The purpose of the present report was to examine differences in ethanol consumption and preference by rats under different housing conditions.

\section{METHOD}

\section{Subjects}

The subjects were nine male and nine female experimentally naive rats of Long-Evans descent (outbred, Charles River Crl:COBS[LE]BR), approximately 2 months of age at the beginning of the experiment.

\footnotetext{
Apparatus

The subjects were housed in one of the three following conditions: (1) Individual cage: Six subjects (three males and three females) were individually housed in stainless steel, wire-
} 
A

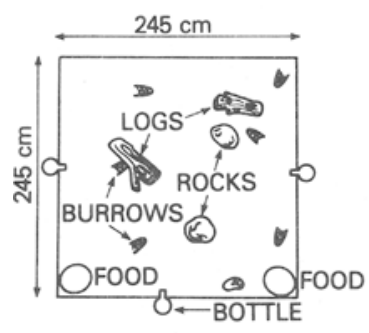

A: COLONY - TOP VIEW
B

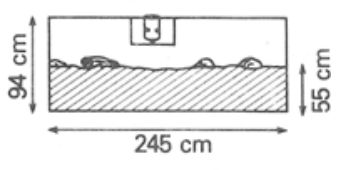

B: COLONY - SIDE VIEW
Figure 1. A schematic of the colonial habitat for Group C.

mesh individual home cages, $20 \mathrm{~cm} \mathrm{~L} \times 25 \mathrm{~cm} \mathrm{~W} \times 19 \mathrm{~cm} \mathrm{H}$. (2) Group cage: Six subjects (three males and three females) were group housed in a single stainless steel group cage, $33 \mathrm{~cm}$ $\mathrm{L} \times 55 \mathrm{~cm} \mathrm{~W} \times 35 \mathrm{~cm} \mathrm{H}$. (3) Colony: Six subjects (three males and three females) were group housed in a large, enclosed wooden colony, $245 \mathrm{~cm} \mathrm{~L} \times 245 \mathrm{~cm} \mathrm{~W} \times 94 \mathrm{~cm} \mathrm{H}$. The colony was filled to $55 \mathrm{~cm}$ with dirt, and rocks and tree segments were distributed throughout. The top of the colony was constructed of wire-mesh, allowing for observation of consumption and social interactions. This apparatus is schematically depicted in Figure 1.

Throughout the experiment, all subjects had continuous access to food (Purina Rat Chow) and an adtib choice of water and one or both of two $10 \%$ ethanol solutions, the specific choice varying with the particular phase of the study. Fluids were presented in drinking tubes fitted with valveless stainless steel spouts. The available fluids were as follows: (1) $\mathrm{H}_{2} \mathrm{O}$-tap water; (2) ETOH-a volumetric (v/v) solution of $10 \%$ ethanol (from U.S.P. 95\%) in tap water; (3) SGNE-a previously described (Kulkosky, 1978, 1979) solution of .125\% sodium saccharin, $3.0 \%$ glucose, $1.0 \%$ sodium chloride, and $10 \% \mathrm{v} / \mathrm{v}$ ethanol in tap water.

Subjects in the individual cages (Group IC) received fluids in three bottles placed along the front wall of the individual home cage. Each bottle was separated by $3 \mathrm{~cm}$. Subjects in the group cage (Group GC) received fluids in three bottles, two placed along the front wall and a third placed on the left wall of the group cage. Each bottle was separated by $20 \mathrm{~cm}$. Subjects in the colony (Group C) received fluids in three bottles placed in the center of the front, left, and right walls of the colony. Each bottle was separated by approximately $173 \mathrm{~cm}$. In all conditions, the spouts protruded approximately $3 \mathrm{~cm}$ into the living chamber.

Food was scattered about the floor along the front wall of the living space. All subjects were maintained under $12: 12$ $\mathrm{L}: \mathrm{D}$ lighting cycle at an ambient temperature of $21^{\circ}-27^{\circ} \mathrm{C}$.

\section{Procedure}

Phase I: Adaptation-Upon receipt in the laboratory, the subjects were assigned randomly to one of three conditions and placed in the appropriate living space. During this phase (25 days), subjects in all conditions had continuous access to $\mathrm{H}_{2} \mathrm{O}$ in all three drinking locations. Phase II: $\mathrm{H}_{2} \mathrm{O}$ vs. ETOH vs. SGNE-On Days $1-16$, all subjects had continuous access to three different fluids, $\mathrm{H}_{2} \mathrm{O}$, ETOH, and SGNE. The relative positions of each of these fluids at the three drinking locations was determined randomly for each of the 16 days of this phase, with the randomization of positions constant for all groups. Phase III: $\mathrm{H}_{2} \mathrm{O}$ vs. ETOH-On Days 17-21, all subjects had continuous access to two different fluids, $\mathrm{H}_{2} \mathrm{O}$ and ETOH. SGNE was removed during this phase. The positions of each of the two solutions in the three drinking locations were determined randomly for each of the 5 days of this phase. The randomization of positions was constant for all three groups.
Throughout all phases of the experiment, the bottles were weighed daily and cleaned every 2 nd day. Fresh fluids were prepared and presented every 2 nd day.

Data were analyzed with one-way analysis of variance with $\mathrm{p}<.05$ as significant.

\section{RESULTS}

The data of one Group IC subject were discarded from analysis because of excessive spillage. All analyses are based on Ns of 5 (Group IC), 6 (Group GC), and 6 (Group C).

\section{Phase I}

During the inital 25-day adaptation phase, mean daily water intakes of Groups IC, GC, and C were $33.0,29.9$, and $29.5 \mathrm{ml}$, respectively. The groups did not differ significantly in the amount of water consumed during this phase $(\mathrm{F}=2.14, \mathrm{df}=2,72, \mathrm{p}>.05)$.

\section{Phase II}

The mean percent of total fluid intake of ETOH for each group during the subsequent 16-day period of Phase II is shown in Figure 2. The three groups showed a small, but significant, difference in percent of total fluid intake as ETOH $(\mathrm{F}=9.5$, $\mathrm{df}=2,45, \mathrm{p}<.05)$. Subjects in the group cage (Group GC) drank a significantly smaller percentage of ETOH (mean $=5.4 \%$ ) than Group IC (mean $=11.8 \%)(\mathrm{F}=18.2, \mathrm{df}=1,45$, $\mathrm{p}<.05)$ and Group $\mathrm{C}($ mean $=9.7 \%)(\mathrm{F}=8.3, \mathrm{df}=1,45$, $\mathrm{p}<.05)$. The intakes of Groups IC and $\mathrm{C}$ did not differ significantly $(\mathrm{F}=1.9, \mathrm{df}=1,45, \mathrm{p}>.05)$.

The mean percent of total fluid intake of SGNE for each group during Phase II is shown in Figure 3. The three groups differed significantly in percent of total fluid intake as SGNE $(\mathrm{F}=55.0, \mathrm{df}=2,45, \mathrm{p}<.05)$. Subjects housed in the colony (Group $\mathrm{C}$ ) drank a significantly smaller percentage of SGNE, flavored ethanol $($ mean $=31.1 \%)$ than Group IC (mean $=51.3 \%)(\mathrm{F}=$ $69.2, \mathrm{df}=1,45, \mathrm{p}<.05)$ and Group GC $($ mean $=54.6 \%)$ $(\mathrm{F}=93.8, \quad \mathrm{df}=1,45, \mathrm{p}<.05)$. The $\mathrm{SGNE}$ intakes

ETOH INTAKE $\stackrel{\leftrightarrow G \text { GROUP IC }}{\circ}$ $\stackrel{\circ}{\triangle} \triangle$ GROUP GC

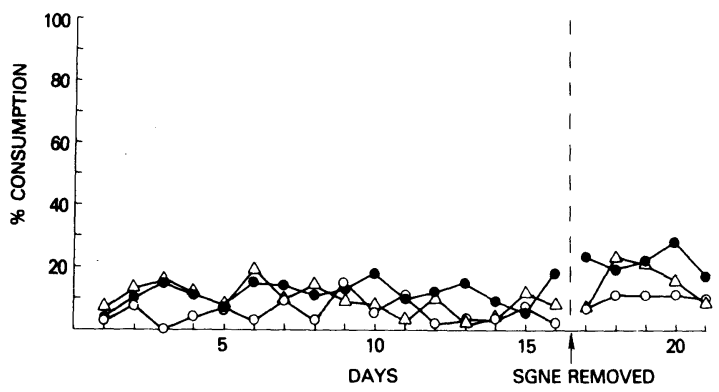

Figure 2. Mean percentage of total fluid intake of ETOH, $10 \%$ ethanol, for Groups IC (individually caged), GC (group caged), and C during Phase II and Phase III. 
of Group IC and Group GC did not differ significantly $(\mathrm{F}=1.86, \mathrm{df}=1,45, \mathrm{p}>.05)$.

The mean percent of total fluid intake of $\mathrm{H}_{2} \mathrm{O}$ for each of the three groups is shown in Figure 4. The three groups differed significantly in the percent of total fluid intake as $\mathrm{H}_{2} \mathrm{O}(\mathrm{F}=34.1$, $\mathrm{df}=2,45, \mathrm{p}<.05)$. Group $\mathrm{C}$ subjects drank a significantly greater percent of $\mathrm{H}_{2} \mathrm{O}$ $($ mean $=59.2 \%)$ than Group IC (mean $=37.2 \%) \quad(\mathrm{F}=$ $57.4, \mathrm{df}=1,45, \mathrm{p}<.05)$ and Group GC (mean $=39.9 \%)$ $(\mathrm{F}=43.9, \mathrm{df}=1,45, \mathrm{p}<.05)$. The $\mathrm{H}_{2} \mathrm{O}$ intakes of Groups IC and GC did not differ significantly $(F=0.9$, $\mathrm{df}=1,45, \mathrm{p}>.05)$.

\section{SGNE INTAKE}
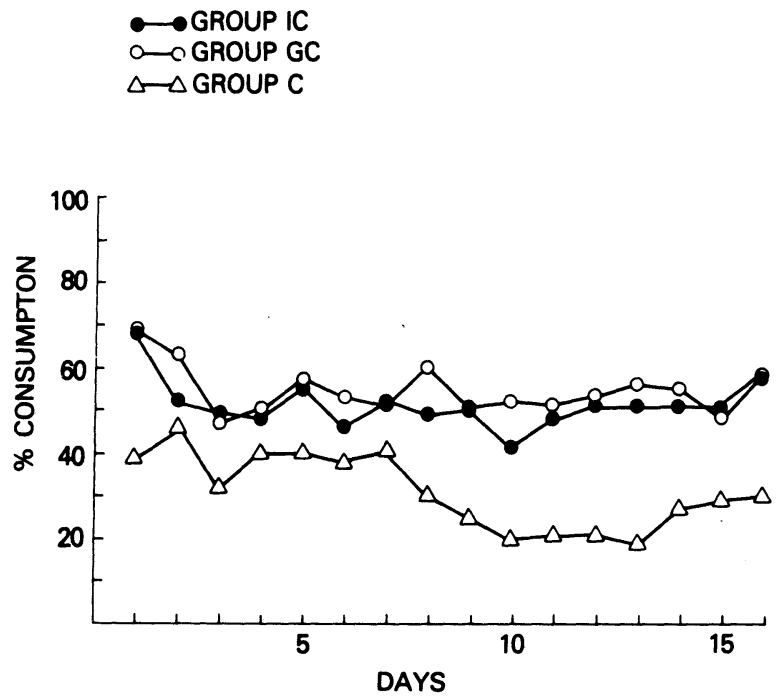

Figure 3. Mean percentage of total fluid intake of SGNE, $10 \%$ ethanol in saccharin + glucose $+\mathrm{NaCl}$ vehicle, for Groups IC, GC, and C during Phase II.

$\mathrm{H}_{2} \mathrm{O}$ INTAKE

$\leftrightarrow$ GROUP IC $\leadsto$ GROUP GC $\leadsto$ GROUP C

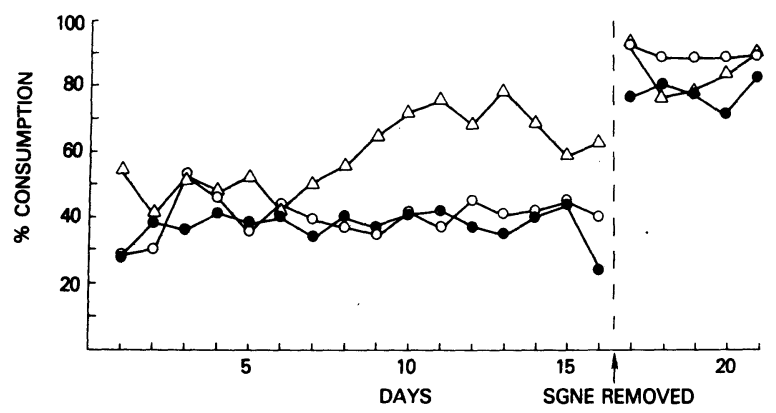

Figure 4. Mean percentage of total fluid intake of $\mathrm{H}_{2} \mathrm{O}$ for Groups IC, GC, and C during Phase II and Phase III.
Table 1

Mean Absolute Fluid Intake (ml) for ETOH, SGNE, $\mathrm{H}_{2} \mathrm{O}$, and Mean Total Fluid Intake $(\mathrm{ml})$ for Groups IC, GC, and $\mathrm{C}$ over the Three Phases of the Experiment.

\begin{tabular}{lccccccccc}
\hline & \multicolumn{3}{c}{ Phase I } & \multicolumn{3}{c}{ Phase II } & \multicolumn{3}{c}{ Phase III } \\
\cline { 2 - 8 } Group & $\mathrm{H}_{2} \mathrm{O}$ & ETOH & SGNE & $\mathrm{H}_{2} \mathrm{O}$ & $\mathrm{T}$ & ETOH & $\mathrm{H}_{2} \mathrm{O}$ & $\mathrm{T}$ \\
\hline IC & 33.0 & 4.7 & 20.2 & 14.8 & 39.7 & 7.4 & 26.7 & 34.1 \\
GC & 29.9 & 2.5 & 24.1 & 17.7 & 44.2 & 4.0 & 35.5 & 39.5 \\
C & 29.5 & 4.3 & 13.5 & 26.1 & 43.9 & 6.6 & 37.6 & 44.2 \\
\hline
\end{tabular}

\section{Phase III}

The mean percent of total fluid intake of ETOH and $\mathrm{H}_{2} \mathrm{O}$ for each of the three groups during Phase III (Days 17-21) is shown in Figures 2 and 4. Following the removal of SGNE at the beginning of Phase III, consumption of ETOH and $\mathrm{H}_{2} \mathrm{O}$ by all groups increased. Although consumption of both fluids increased above levels consumed in Phase II, $\mathrm{H}_{2} \mathrm{O}$ was greatly and consistently preferred to ETOH for all groups.

The mean percent of total fluid intake of ETOH was significantly different for the three groups of rats $(\mathrm{F}=7.4$, $\mathrm{df}=2,12, \mathrm{p}<.05)$. Subjects housed in individual cages (Group IC) drank a significantly larger percent $($ mean $=21.8 \%)$ than Group GC $($ mean $=10.0 \%)$ $(\mathrm{F}=14.7, \mathrm{df}=1,12, \mathrm{p}<.05)$, but did not differ significantly from Group $C($ mean $=15.2 \%)(F=4.6, d f=1,12$, $\mathrm{p}>.05$ ). The ETOH intakes of Groups GC and $\mathrm{C}$ did not differ significantly $(\mathrm{F}=2.9$, $\mathrm{df}=1,12, \mathrm{p}>.05)$.

The mean grams of total ethanol intake (TEI, weight of absolute ethanol from ETOH + SGNE) for Phase II was $2.0,2.1$, and $1.4 \mathrm{~g} /$ rat for Groups IC, GC, and C, respectively. The groups differed significantly in TEI during this period (Days 1-16) $(\mathrm{F}=16.9$, $\mathrm{df}=2,45$, $\mathrm{p}<.05)$. Group $\mathrm{C}$, colony-housed rats, drank significantly less total ethanol than Group IC $(\mathrm{F}=19.6$, $\mathrm{df}=1,45, \mathrm{p}<.05)$ and Group GC $(\mathrm{F}=30.0, \mathrm{df}=1,45$, $\mathrm{p}<.05$ ), but TEI for Groups IC and GC did not differ significantly $(\mathrm{F}=1.1, \mathrm{df}=1,45, \mathrm{p}>.05)$.

The mean TEI for Phase III was $.6, .34$, and $.52 \mathrm{~g} / \mathrm{rat}$ for Groups IC, GC, and C, respectively. There were no significant differences in total grams of ethanol consumed per rat among any of the three groups across Phase III $(F=3.3, \mathrm{df}=2,12, \mathrm{p}>.05)$.

Mean absolute intakes of ETOH, SGNE, and $\mathrm{H}_{2} \mathrm{O}$ as well as total fluid intake for each group across the three phases of the study are summarized in Table 1 .

\section{DISCUSSION}

Given a three-bottle choice of water, $10 \%$ ethanol, and $10 \%$ ethanol in a sweetened and salty vehicle, rats housed in a naturalistic colonial environment ingested significantly lower percentages of the flavored ethanol solution and lower amounts of total ethanol than either 
individually or group-caged rats. When the choice of flavored ethanol was removed, total ethanol intake for all groups greatly decreased, and did not differ significantly among the groups. These findings are consistent with the often-reported elevation of ethanol intake by the addition of sweeteners (Cullen et al., 1973; Eriksson, 1969; Geiger \& Barker, 1976; Gilbert, 1974; Kulkosky, 1978, 1979; Myers \& Tytell, 1972; Rodgers \& McClearn, 1964; Samson \& Falk, 1974) and reports of immediately lowered ethanol intake by rats after removal of sapid congeners (Cullen et al., 1973; Geiger \& Barker, 1976; Kulkosky, 1979).

A crowding and isolation stress explanation of the finding of lowered total ethanol intake by rats in a colonial habitat is plausible. Rats in a colonial habitat have far greater floor area $\left(10,004 \mathrm{~cm}^{2} / \mathrm{rat}\right)$ than either individually housed animals $\left(500 \mathrm{~cm}^{2} / \mathrm{rat}\right)$ or grouphoused animals $\left(302.5 \mathrm{~cm}^{2} / \mathrm{rat}\right)$. The colonial rats also had the opportunity to expand the area per animal by burrowing. The area per rat in the colony greatly exceeds the areas per animal previously used in grouping studies (see Hannon \& Donlon-Bantz, 1976). If stress acts to increase ethanol consumption (for reviews, see Lester, 1966; Lester \& Freed, 1973; Myers, 1966; Myers \& Veale, 1972; Wallgren \& Barry, 1970), and isolation or crowding act as effective stressors (Brown, 1968; Deatherage, 1972; Fox, 1974; Hannon \& DonlonBantz, 1975, 1976; Hatch et al., 1963; Heminway \& Furumoto, 1972; Lovely et al., 1972; Parker \& Radow, 1974; Rodgers \& Thiessen, 1964; Thiessen, 1964; Thiessen \& Rodgers, 1961, 1965; Welch, 1974), the data may be explained as a response to stress of increased intake of ethanol in the flavored solution. However, there were no significant differences in total ethanol intake among the groups when the choice of flavored ethanol was removed. The above explanation, therefore, can only be possible for ethanol consumption when maximized by the addition of sapid solutes so that resultant blood ethanol levels are sufficiently high to exert psychopharmacological effect (Kulkosky, 1979).

However, other explanations might also be compatible with the observed results. For example, taste preferences might conceivably be different in the colony because contact is permitted with soil, tree segments, rocks, etc. (e.g., geophagia was observed in the colony). Nevertheless, colony-housed rats showed a nearly exclusive preference for the ethanol-free saccharin + glucose + $\mathrm{NaCl}$ vehicle in two-bottle tests against water, which was nearly identical to that of individually housed rats (Kulkosky, 1979; Kulkosky, Zellner, Hyson, \& Riley, Note 1). Thus, an explanation of the lowered flavoredethanol intake as an effect of altered taste preferences in the colony for the sapid vehicle appears unlikely.

The action of social stimuli other than simple propinquity might prove responsible for the relatively lower total ethanol intake in the colony. Adequate room for the establishment of territoriality and dominance hierarchies or the formation of "local tradition" (EiblEibesfeldt, 1970) of drinking might be cited as possible influences on flavored ethanol intake. More detailed study of social and environmental interactions in naturalistic colonies should further clarify the factors responsible for the relatively decreased total ethanol intake in a colonial habitat (Moran, 1975; Woods \& Kenney, 1979).

In summary, when rats are offered a flavored ethanol solution, subjects housed in a naturalistic colonial habitat consume significantly less total ethanol than rats housed in individual or group cages. The data suggest that the stimuli of the colonial habitat act to decrease maximized ethanol intake.

\section{REFERENCE NOTE}

1. Kulkosky, P. J., Zellner, D. A., Hyson, R. L., \& Riley, A. L. Ethanol intake by rats in a colonial housing situation. Paper presented at the annual meeting of the Chemical Senses and Intake Society, Washington, D.C., March 1978.

\section{REFERENCES}

BARRY, H., III. Sociocultural aspects of alcohol addiction. In A. Wikler (Ed.), The addictive states (Association for Research in Nervous and Mental Disease, Research Publications Vol. 46). Baltimore: Williams \& Wilkins, 1968.

Brown, R. V. Effects of stress on voluntary alcohol consumption in mice. Quarterly Journal of Studies on Alcohol, 1968, 29, 49-53.

Cullen, J. W., Croes, R. A., \& Gillis, R. D. Alcohol selection by rats after experience with a sapid alcohol-sucrose solution. Quarterly Journal of Studies on Alcohol, 1973, 34, 769-773.

Deatherage, G. Effects of housing density on alcohol intake in the rat. Physiology \& Behavior, 1972, 9, 55-57.

Eibl-Eibesfeldt, I. Ethology: The biology of behavior. New York: Holt, Rinehart and Winston, 1970.

Eriksson, K. Factors affecting voluntary alcohol consumption in the albino rat. Annales Zoologici Fennici, 1969, 6, 227-265.

Fox, M. W. Space and social distance in the ecology of laboratory animals. In H. Magalhaes (Ed.), Environmental variables in animal experimentation. Lewisburg, Pa: Bucknell University Press, 1974.

Geiger, J. F., \& BArker, L. M. Alcohol consumption by rat and mouse strains: Functions of taste and alcohol deprivation. Journal of Studies on Alcohol, 1976, 37, 950-958.

GiLBERT, R. M. Effects of food deprivation and fluid sweetening on alcohol consumption by rats. Quarterly Journal of Studies on Alcohol, 1974, 35, 42-47.

Hannon, R., \& Donlon-Bantz, K. Effects of crowding on alcohol consumption by rats. Journal of Studies on Alcohol, 1975, 36, 1273-1276.

Hannon, R., \& Donlon-Bantz, K. Effect of housing density on alcohol consumption by rats. Journal of Studies on Alcohol, 1976, 37, 1556-1563.

Hatch, A., Wiberg, G. S., Balazs, T., \& Grice, H. C. Long-term isolation stress in rats. Science, 1963, 142, 507.

Heminway, D. A., \& Furumoto, L. Population density and alcohol consumption in the rat. Quarterly Journal of Studies on Alcohol, 1972, 33, 794-799.

Kulkosky, P. J. Free-selection ethanol intake of the golden hamster (Mesocricetus auratus). Physiological Psychology, $1978,6,505-509$ 
Kulkosky, P. J. Effect of addition of ethanol and $\mathrm{NaCl}$ on saccharin + glucose polydipsia. Pharmacology, Biochemistry \& Behavior, 1979, 10, 277-283.

LESTE R, D. Self-selection of alcohol by animals, human variation, and the etiology of alcoholism: A critical review. Quarterly Journal of Studies on Alcohol, 1966, 27, 395-438.

Lester, D., \& Freed, E. X. Criteria for an animal model of alcoholism. Pharmacology, Biochemistry \& Behavior, 1973, 1, 103-107.

Lovely, R. H., Pagano, R. R., \& Paolino, R. M. Shuttlebox-avoidance performance and basal corticosterone levels as a function of duration of individual housing in rats. Journal of Comparative and Physiological Psychology, 1972, 81, 331-335.

Mardones, J. Experimentally induced changes in the free selection of ethanol. International Review of Neurobiology, 1960, 2, 41-76.

MELlo, N. K. A review of methods to induce alcohol addiction in animals. Pharmacology, Biochemistry \& Behavior, 1973, 1, 89-101.

MeLlo, N. K. Animal models for the study of alcohol addiction. Psychoneuroendocrinology, 1976, 1, 347-357.

Moran, G. Severe food deprivation: Some thoughts regarding its exclusive use. Psychological Bulletin, 1975, 82, 543-557.

MyERS, R. D. Voluntary alcohol consumption in animals: Peripheral and intracerebral factors. Psychosomatic Medicine, 1966, 28, 484-497.

Myers, R. D., \& Tytell, M. Volitional consumption of flavored ethanol solution by rats: The effects of pCPA, and the absence of tolerance. Physiology \& Behavior, 1972, 8, 403-408.

Myers, R. D., \& Veale, W. L. The determinants of alcohol preference in animals. In B. Kissin \& H. Begleiter (Eds.), The biology of alcoholism (Vol. 2) Physiology and behavior. New York: Plenum, 1972.

NoBle, E. P. (Ed.). Third special report to the U.S. Congress on alcohol and health from the Secretary of Health, Education, and Welfare. Washington, D.C: U.S. Government Printing Office, 1978.

Paré, W. P., \& Temple, L. J. Food deprivation, shock stress and stomach lesions in the rat. Physiology \& Behavior, 1973, 11, 371-375.

Parker, L. F., \& Radow, B. L. Isolation stress and volitional ethanol consumption in the rat. Physiology \& Behavior, 1974, 12, 1-3.
Richter, C. P. Production and control of alcoholic cravings in rats. In H. A. Abramson (Ed.), Neuropharmacology: Transactions of the third conference. New York: Josiah Macy, Jr., Foundation, 1957.

Rodgers, D. A., \& McClearn, G. E. Sucrose versus ethanol appetite in inbred strains of mice. Quarterly Journal of Studies on Alcohol, 1964, 25, 26-35.

Rodgers, D. A., \& Thiessen, D. D. Effects of population density on adrenal size, behavioral arousal, and alcohol preference of inbred mice. Quarterly Journal of Studies on Alcohol, 1964, 25, 240-247.

Samson, H. H., \& Falk, J. L. Schedule-induced ethanol polydipsia: Enhancement by saccharin. Pharmacology, Biochemistry \& Behavior, 1974, 2, 835-838.

Slighter, R. G., Jr. Alcohol selection and position selection in hamsters caged singly and in groups. Quarterly Journal of Studies on Alcohol, 1970, 31, 20-27.

Thiessen, D. D. Population density and behavior: A review of theoretical and physiological contributions. Texas Reports on Biology and Medicine, 1964, 22, 266-314.

Thiessen, D. D., \& Rodgers, D. A. Population density and endocrine function. Psychological Bulletin, 1961, 58, 441-451.

Thiessen, D. D., \& Rodgers, D. A. Alcohol injection, grouping, and voluntary alcohol consumption of inbred strains of mice. Quarterly Journal of Studies on Alcohol, 1965, 26, 378-383.

Wallgren, H., \& Barry, H., III. Actions of alcohol. New York: Elsevier, 1970.

WeLCh, B. L. Sound and social environment as variables in animal experimentation. In H. Magalhaes (Ed.), Environmental variables in animal experimentation. Lewisburg, $\mathrm{Pa}$ : Bucknell University Press, 1974.

Wilson, C. W. M. An analysis of the mechanisms involved in the taste for drink. In H. Steinberg (Ed.), Scientific basis of drug dependence. London: Churchill, 1969.

Wise, R. A. Maximization of ethanol intake in the rat. In M. M. Gross (Ed.), Alcohol intoxication and withdrawal: Experimental studies II. Advances in experimental medicine and biology (Vol. 59). New York: Plenum, 1975.

Woods, S. C., \& KenNey, N. J. Alternatives to homeostasis. The Behavioral and Brain Sciences, 1979, 2, 123-124.

(Received for publication October 1, 1979; accepted December 19, 1979.) 